\title{
Feeding systems in summer dry environments for red deer in lactation
}

\author{
D.R. STEVENS and I.D. CORSON \\ AgResearch Invermay, Private Bag 50034, Mosgiel \\ david.stevens@agresearch.co.nz
}

\begin{abstract}
An analysis of the pasture growth pattern in a summerdry environment compared with the feed requirements of breeding hinds shows that the inclusion of a brassica crop can improve feed supply. The impacts of summer crops on productivity of hinds and calves in a summer dry climate was tested by comparing a single use forage rape and a specialist crop of chicory, plantain and clovers, and undersowing a forage crop with a perennial pasture mix to remove the need to re-establish pasture once the crop was used. Calf liveweight gain ranged from 424 to $455 \mathrm{~g} / \mathrm{d}$ between birth and weaning in early March but did not differ significantly between the forage systems. Hind liveweight change was negatively related to the amount of forage on offer, with hinds beginning to lose weight when forage covers for each crop mix fell below about $1850 \mathrm{~kg} \mathrm{DM} / \mathrm{ha}$. As the amount of new pasture in the system increased after cropping the need for large areas of summer crops declined, suggesting constant re-evaluation of the role of summer crops in supplying extra forage to fill feed shortfalls is necessary.
\end{abstract}

Keywords: feed supply, forage systems, growth rate, lactation

\section{Introduction}

Pasture quality and quantity can both be less than adequate for lactation of red deer during dry summers (Nicol et al. 2000). Brassicas can provide large forage quantities and high quality at this time of the year (Chapman et al. 2006; Clark et al. 1996). A key issue is how brassicas fit into a grazing system, rather than being an ad hoc addition to provide summer feed (Shaw et al. 1997; Stevens 2009).

There are many factors that may alter the response of grazing animals to use of brassica crops. For instance, adaptation time or the time needed to alter the rumen microbial populations to effectively use a brassica crop, poses a significant risk and production cost if not done correctly (Stevens \& Corson 2003). The type of crop may alter the overall outcome (Stevens 2009). A single use crop like turnips with a high short term yield but longer crop growth period contrasts with a multiple use crop like rape, which can provide feed over a longer time-frame through repeat grazing with less crop growth time before the first grazing.

While brassica crops can be used alone, this is never the case in the whole system so the ratio between pasture and crop needs to be defined (Stevens 2009). Unproductive time during the establishment of the crop and then re-establishment of pasture are key factors which drive the overall productivity of a grazing system which includes brassicas. Finally, the size of the contribution of the crop compared with the seasonal requirements for grazing stock will help decide the practical uses of brassica crops.

An analysis of the pasture growth pattern in the summer dry environment of Flock House, Manawatu (Radcliffe 1976) compared with the feed requirements of a breeding hind herd (Mulley 2003) shows that the inclusion of a large area of brassica crop may assist to fill the feed deficit during lactation (Fig. 1).

Other additions to a forage brassica may help add to both the nutritional and productive potential of a crop, or may help replace one by providing a perennial alternative. The potential of forages such as chicory, red clover and plantain have been demonstrated with weaners (Hoskin et al. 2003; Nicol \& Barry 2003) and may provide some extra productivity for summer hind lactation as well.

The current experiment aimed to determine the impacts of summer crops on the productivity of red deer hinds and calves in a summer-dry climate. Crop options included a single use forage rape and a specialist crop of chicory, plantain and clovers, as well as undersowing

Figure 1 The profile of available forage of an unimproved pasture or a system with the inclusion of $33 \%$ of the area as a brassica crop sown in early November and utilised during January, February and March compared to the feed requirements of breeding hinds at $6 /$ ha in a summer dry environment.

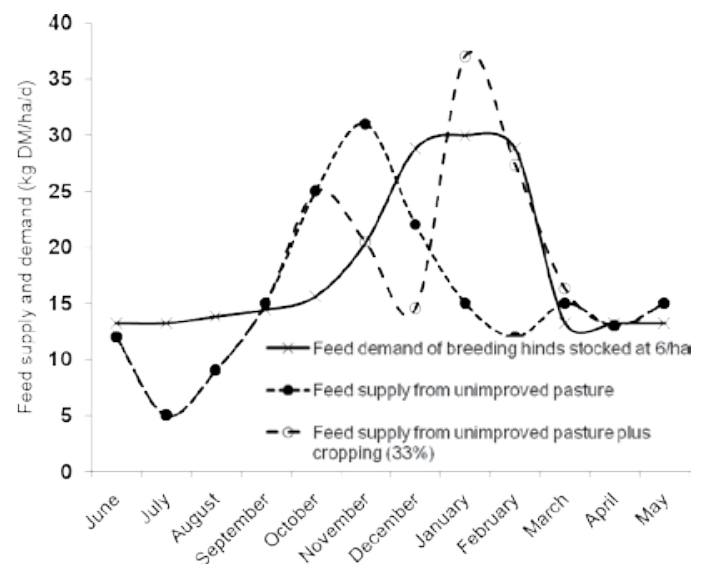


the crop with a perennial pasture mix to remove the need to re-establish pasture once the crop was used.

\section{Methods and Materials}

A systems experiment was run over 2 years in the summer-dry environment on a Rangitikei loamy sand (Cowie et al. 1967) classified as a Typic Udipsamment mixed mesic soil at the Flock House Research Station (40 16'S, $\left.175^{\circ} 17^{\prime} \mathrm{E}\right)$. Multiparous, pregnant red deer hinds $(n=240)$ were randomly allocated to one of four groups of 60 in early October each year to be calved separately. Each group was adjusted to achieve the same stocking rate of 8.5 hinds/ha and allocated to one of four treatments during the summer lactation period.

The treatments were:

1. Pasture Control - Semi-improved pasture $(40 \%$ in perennial ryegrass/white clover pastures under 5 years old)

2. Single use crop - 'Winfred' rape, re-sown into perennial ryegrass/white clover pasture in April each year

3. Undersown perennial pasture - Crop plus pasture including 'Winfred' rape, 'Cannon' perennial AR1 ryegrass, 'Grouse' chicory, 'Tonic' plantain, 'Colenso' red clover, and 'Prestige' white clover

4. Specialist - Crop of 'Winfred' rape, plus specialist species 'Grouse' chicory, 'Tonic' plantain, 'Colenso' red clover and 'Prestige' white clover which was then used in Year 2 with no re-sowing.

Twenty-eight to $39 \%$ of the grazing area was sown in crops on 1 November and 8 November in Years 1 and 2 , respectively (Table 1). Paddock records for each herd were taken to determine the total amount of area used throughout the experiment. The herds in treatments 2,3 and 4 were on pasture during calving and until transfer to their respective crops in late December, while still having pasture available throughout. Hinds and calves were gradually introduced to their respective crops over 10 days and were monitored daily, to ensure adaptation to potential toxins including plant nitrate, glucosinolates and S-methyl cysteine sulphoxide. No signs of toxicity were seen. A slow rotation was used to occasionally spell crops and pastures, though they were used continuously between late January and late February. In the Pasture Control treatment hinds and calves were stocked on pasture only and continuously grazed during calving. A slow rotational grazing system was then used from 20 December (after calving). Surplus pasture growth was controlled by removing animal access to some of the grazing area for conservation in mid-October. Feed availability was allocated to achieve an intake of between 35 and $50 \mathrm{MJ}$ ME/hind per day, with a minimum residual pasture mass of $1000 \mathrm{~kg} \mathrm{DM} /$ ha after grazing.

Hinds were weighed at the beginning of lactation, midlactation and at weaning. Calves were weighed in midlactation and at weaning. No animal health treatments were given during lactation. Crop and pasture yields were measured throughout the experiment. Other feed conservation and supplementary feed use was recorded.

Calf liveweight gain was calculated for early lactation (birth to late January) and late lactation (late January to early March). A mean birth weight of 10.5 and $10.8 \mathrm{~kg}$ were used for hind and stag calves, respectively, with an observed mean calving date of 24 November. Hind weight changes were calculated for early lactation (from mid-October, pre-calving, to late January) and late lactation. Data were analysed using the general linear model function of the GenStat analysis software with forage mix as the fixed effect and year as the variable effect (GenStat 2007). Data were also analysed by combining both Year 1 and Year 2 to investigate the effects of variation in the amount of forage available on both calf and hind liveweight change. This experiment was assessed and approved for animal ethical considerations by the Palmerston North Crown Research Institute Animal Ethics Committee.

\section{Results}

Pasture and crop covers in the different forage systems for the 2 years (Fig. 2) showed the high degree of variability between each year. Climate records for the 2 years show the large variations in potential soil

Table 1

Area sown and forage seeding rates $(\mathrm{kg} / \mathrm{ha})$ of the three cropping treatments.

\begin{tabular}{llccc}
\hline & & Single use crop & $\begin{array}{c}\text { Undersown perennial } \\
\text { pasture }\end{array}$ & Specialist \\
\hline Area in Crop (\%) & Year 1 & 28 & 34 & 39 \\
& Year 2 & 33 & 37 & 39 \\
\hline Seeding rate (kg/ha) & 'Winfred' rape & 3 & 3 & 3 \\
& 'Grouse' chicory & & 2 & 2 \\
& 'Tonic' plantain & 2 & 5 \\
& 'Colenso' red clover & 5 & 3 \\
& 'Prestige' white clover & 3 & 12 \\
& 'Cannon' AR1 perennial ryegrass & & 3 \\
\hline
\end{tabular}


moisture deficit and the different times when it occurred (Fig. 3). When analysed over the 2 years the Specialist mix had the highest average crop cover $(\mathrm{P}=0.002$; Table 2) with the Undersown perennial pasture mix being intermediate and the Single use mix having the lowest average crop cover. Pasture covers on offer did not differ significantly between treatments or years.

Calf liveweight gain ranged from 424 to $455 \mathrm{~g} / \mathrm{d}$ between birth and weaning in early March but did not

Figure 2 Variations in available forage on offer in four systems stocked at 8.5 hinds and their calves per ha during lactation in a summer-dry environment (Key: Solid lines $=$ Year 1; Dotted lines $=$ Year 2; $\times$ Pasture control; $\diamond$ Single use crop; $\circ$ Undersown perennial pasture; $\square$ Specialist)

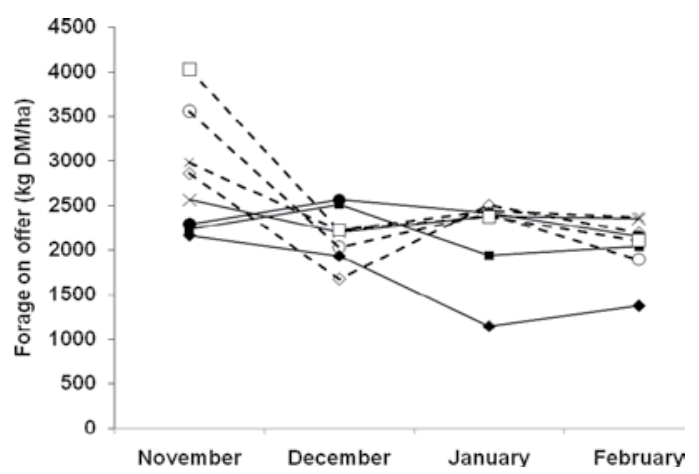

differ significantly between the forage systems (Table 2a). Average hind liveweight change was positive over lactation (October-March) and again was not significantly affected by forage system (Table 2a).

The performance of the systems was also analysed to examine variations in early and late lactation (Table $2 b$ ). Calf growth rate in early lactation was higher than that achieved in late lactation $(\mathrm{P}<0.001)$. Average hind liveweight gain was also higher in early lactation than

Figure 3 Rainfall and potential soil moisture deficit patterns during the 2 years of the forage systems experiment. The available water holding capacity of these soils is approximaltey $75-100 \mathrm{~mm}$, with pasture growth restrictions occurring at a deficit greater than $50 \mathrm{~mm}$.

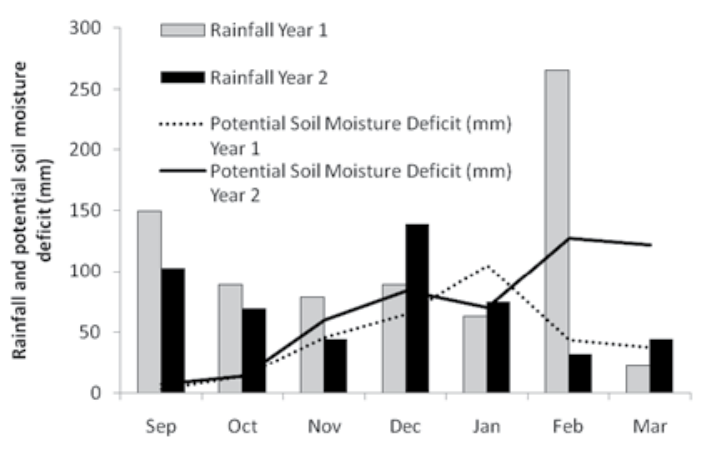

Table 2 Average forage yields and liveweight change for red deer calves and hinds over 2 years using different pasture and crop mixtures during the summer lactation period.

\begin{tabular}{|c|c|c|c|c|c|c|}
\hline \multirow[t]{2}{*}{ (a) } & & \multicolumn{4}{|c|}{ Forage system } & \multirow[b]{2}{*}{ SED } \\
\hline & & $\begin{array}{l}\text { Pasture } \\
\text { control }\end{array}$ & Single use crop & $\begin{array}{c}\text { Undersown } \\
\text { perennial pasture }\end{array}$ & Specialist & \\
\hline \multicolumn{7}{|c|}{ Forage yields on offer (kg DM/ha) } \\
\hline & Crop & - & $1250 b^{1}$ & $1593 a b$ & $2266 \mathrm{a}$ & 349 \\
\hline & Pasture & 2410 & 2063 & 2467 & 2072 & 223 \\
\hline & Forage & 2410 & 1830 & 2313 & 2254 & 197 \\
\hline \multicolumn{7}{|c|}{ Liveweight change (g/d) } \\
\hline & Calves & 450 & 435 & 424 & 455 & 21 \\
\hline & Hinds & 75 & 37 & 22 & 67 & 103 \\
\hline \multirow[t]{2}{*}{ (b) } & & & \multicolumn{2}{|c|}{ Lactation period } & & \\
\hline & & & $\begin{array}{c}\text { Birth to late } \\
\text { January }\end{array}$ & $\begin{array}{l}\text { Late January to } \\
\text { weaning }\end{array}$ & SED & \\
\hline \multicolumn{7}{|c|}{ Forage yields on offer (kg DM/ha) } \\
\hline & Crop & & 1506 & 1048 & 247 & \\
\hline & Pasture & & 2387 & 2119 & 158 & \\
\hline & Forage & & 2399 & 2004 & 140 & \\
\hline \multicolumn{7}{|c|}{ Liveweight change $(\mathrm{g} / \mathrm{d})$} \\
\hline & Calves & & 496 & 386 & 15 & \\
\hline & Hinds & & 98 & 2 & 31 & \\
\hline
\end{tabular}

\footnotetext{
${ }^{1}$ Values with the same letter are not significantly different.
} 
Figure 4 Red deer calf growth rates in early and late lactation in relationship to the available forage over 2 years across all pasture and crop mix groups.

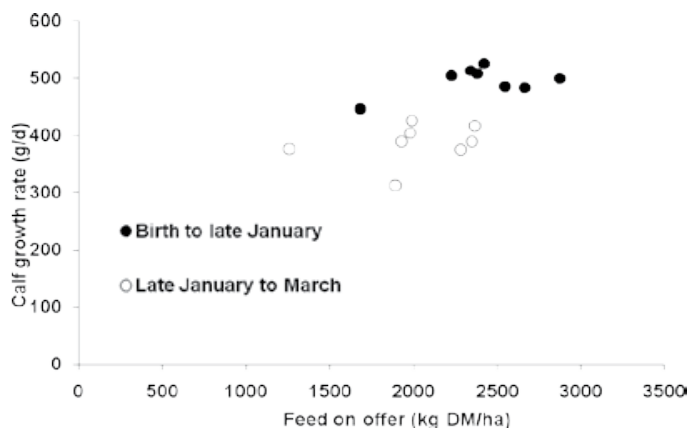

Figure 6 A re-evaluation of the feed supply and demand of different forage options for a summer-dry environment.

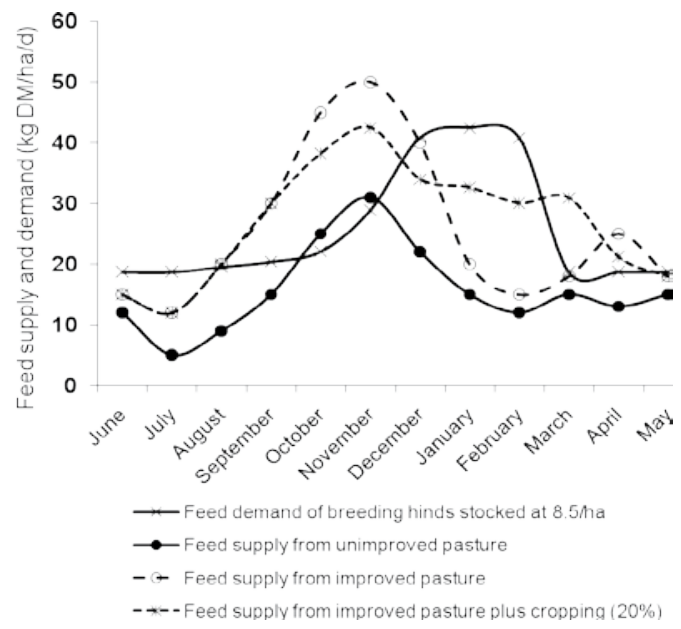

late lactation $(\mathrm{P}=0.016)$. Total forage yield on offer was also correspondingly higher in early than in late lactation.

No supplementary feed was used. In Year 1 there was $5520 \mathrm{~kg}$ DM harvested as baleage from 1.5 ha of the Control treatment on December 4. In Year 2 baleage was made from the Specialist, Single use and Undersown perennial pasture cropping systems, yielding 10560,3360 and $960 \mathrm{~kg} \mathrm{DM}$, respectively.

The relationship between the feed availability and animal performance was analysed using the data from both years to help understand the relationship between total forage supply and calf (Fig. 4) and hind (Fig. 5) performance. There was no relationship between calf growth rate and forage on offer, with consistent calf performance regardless of the amount of forage on offer. Hind liveweight change was negatively related to the amount of forage on offer, with hinds beginning to lose weight when forage covers on the system fell below about $1850 \mathrm{~kg} \mathrm{DM} / \mathrm{ha}$.
Figure 5 Relationship between the amount of forage on offer and liveweight change in lactating hinds across all pasture and crop mix groups over 2 years.

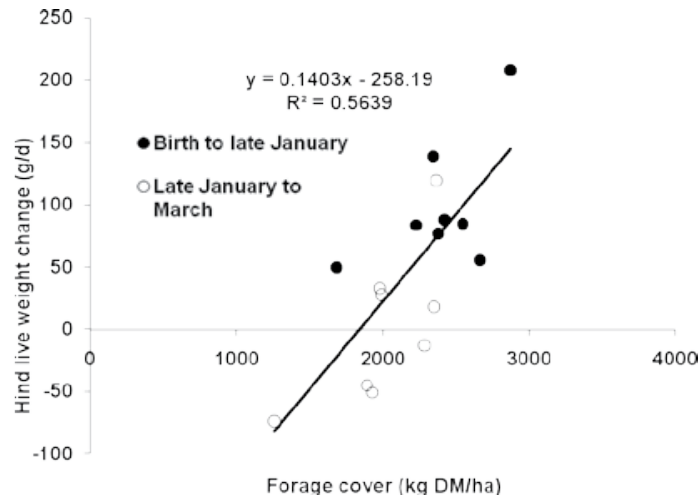

\section{Discussion}

Spring pasture growth was similar between years, but dry conditions in late spring and summer had a greater effect on the growth of the crop before grazing began in Year 2 with relative yield being halved compared with Year 1. However, the soil moisture deficit estimate during January in Year 1 indicated little or no water was available for plant growth and was associated with the coincident rapid decline in the average cover of the crops. In contrast, the available crop grazing yields in Year 2 improved during January as rainfall sustained growth. The soil moisture deficits (Fig. 3) and the pasture growth curve (Radcliffe 1976) are representative of other dry regions of New Zealand, showing similar pasture growth characteristics to the Wairarapa and Hawkes Bay (Radcliffe 1975), Canterbury (Rickard \& Radcliffe 1976) and North and East Otago (McNamara 1992).

The introduction of a Specialist mixture under crop in Year 1 provided the opportunity to harvest much more baleage during Year 2. This provided surety of yield before its use for late lactation feeding. One premise of using a 'crop' is to provide high quality feed during late lactation. However, this research indicates that the amount of feed on offer is much more important. When feed covers dropped below about $1850 \mathrm{~kg} \mathrm{DM} / \mathrm{ha}$ then hind liveweight began to fall. This coincided with the latter part of lactation when calf intake was increasing and feed supply was diminishing due to the onset of summer-dry soil conditions (Fig. 3). This suggests that using crops from late December may be too early to maximise the benefits, though this time was chosen as the optimum to begin crop introduction based of feed budget analysis (Fig. 1). A key feature that would improve this situation is earlier sowing of the crops.

A feature of all cropping mixes tested was the establishment of new pastures, achieving the overall 
aim of 30 to $35 \%$ pasture renewal. This high amount of renewal provided the opportunity to keep pasture covers lower in late spring, thus keeping pasture quality high. The large amount of cropping also shifts enough high quality feed from spring into summer to ensure that the crop made a real difference to the year round grazing system. Once a large area is re-established in new pasture, a re-evaluation of each of the grazing mixes trialled will be needed, as the base pasture productivity is changed. A predictive analysis (Fig. 6) shows that with some carry-over of a feed wedge into summer a good fit maintains a stocking rate of 8.5 hinds/ha with a shift to earlier sowing (early October) and a smaller area $(20 \%)$ of crop.

The use of the Specialist crop of chicory, plantain, red and white clover provided high quality baleage during Year 2, as well as having a more drought-tolerant 'crop' of high quality for grazing lactating hinds and their calves during dry conditions. All cropping systems provided toxin-free forage while calves were growing and undersowing pasture species gave toxin-free forage for weaning.

The management of forage during the summer was the most important feature that helped maintain high weaner weight in red deer. However, the opportunities provided by high rates of pasture renewal did provide a forage management environment that helped meet key targets of maximising late summer hind and calf performance.

\section{ACKNOWLEDGEMENTS}

Many thanks to the AgResearch Farm Staff at Flock House, to PGG Wrightson for seed and funding and the Foundation for Research, Science and Technology for funding.

\section{REFERENCES}

Chapman, D.F.; Jacobs, J.L.; Ward, G.N.; O'Brien, G.B.; Kenny, S.N.; Beca, D.; McKenzie, F.R. 2006. Forage supply systems for dryland dairy farms in southern Australia. Proceedings of the New Zealand Grassland Association 68: 255-260.

Clark, D.A.; Howse, S.W.; Johnson, R.J.; Pearson, A.; Penno, J.W.; Thomson, N.A. 1996. Turnips for summer milk production. Proceedings of the New Zealand Grassland Association 57: 145-150.

Cowie, J.D.; Fitzgerald, P.; Owers, W. 1967. Soils of the Manawatu-Rangitikei sand country. New Zealand Soil Bureau Bulletin 29: 1-58.

GenStat 2007. GenStat for Windows. VSN International Ltd, Oxford.

Hoskin, S.O.; Barry, T.N.; Wilson, P.R. 2003. The review of plants containing secondary compounds in sustainable deer farming - a review. The nutrition and management of deer on grazing systems. Grassland Research and Practice Series 9: 101-112.

McNamara, R.M. 1992. Seasonal distribution of pasture production in New Zealand. XX. North Otago and East Otago downlands. New Zealand Journal of Agricultural Research 35: 163-169.

Mulley, R.C. 2003. The feed requirements of adult red deer. The nutrition and management of deer on grazing systems. Grassland Research and Practice Series 9: 51-56.

Nicol, A.M.; Barry, T.N. 2003. Pasture and forages for deer growth. The nutrition and management of deer on grazing systems. Grassland Research and Practice Series 9: 25-40.

Nicol, A.M.; Judson, H.G.; Stevens, D.R.; Beatson, N.S. 2000. The productivity of deer grazing permanent pasture. Asian-Australasian Journal of Animal Sciences 13: 46-48.

Radcliffe, J.E. 1975. Seasonal distribution of pasture production in New Zealand. VII. Masterton (Wairarapa) and Maraekakaho (Hawke's Bay). New Zealand Journal of Experimental Agriculture 3: 259265.

Radcliffe, J.E. 1976. Seasonal distribution of pasture production in New Zealand. X. Rangitikei district. New Zealand Journal of Experimental Agriculture 4: 163-170.

Rickard, D.S.; Radcliffe, J.E. 1976. Seasonal distribution of pasture production in New Zealand. XII. Winchmore, Canterbury Plains dryland and irrigated pastures. New Zealand Journal of Experimental Agriculture 4: 329-335.

Shaw, R.J.; Thomson, N.A.; McGrath, D.F.; Dawson, J.E. 1997. More summer milk - an on-farm demonstration of research principles. Proceedings of the New Zealand Grassland Association 59: 149-155.

Stevens, D.R. 2009. Choice of forage crops for animal production in temperate perennial pasture-based grazing systems. p. 9. In: CAB Reviews: Prespectives in Agriculture, Veterinary Science, Nutrition and Natural Resources 4. 017.

Stevens, D.R.; Corson, I.D. 2003. Effects of winter feed type on feed intake during the transition back to spring pasture. The nutrition and management of deer on grazing systems. Grassland Research and Practice Series 9: 45-50. 